\title{
Mortality among patients with non-affective functional psychoses in a metropolitan area of South-Eastern Brazil*
}

\author{
Mortalidade em pacientes com psicoses funcionais não afetivas na \\ cidade de São Paulo, Brasil
}

\author{
Paulo R. Menezes and Anthony H. Mann \\ Section of Epidemiology and General Practice. Institute of Psychiatry, U.K.
}

\begin{abstract}
High mortality rates among those suffering from schizophrenia and related psychoses have been consistently described in developed societies. However, to date there is a lack of data on this matter in Brazil. In order to examine this issue, a prospective 2-year follow-up study was carried out in S. Paulo. The sample consisted of 120 consecutive admissions to psychiatric hospitals in a defined catchment area, aged 18 to 44 years old, with clinical diagnoses of nonaffective functional psychoses according to the ICD-9. After 2 years, 116 $(96.7 \%)$ subjects were traced. During the study period there were 7 deaths (6.0\% of those traced), $5(4.3 \%)$ due to suicide. All but one of the suicides occurred in the first year after discharge from hospital. Age and sex Standardised Mortality Ratios (relative to rates for the population of the city of Sao Paulo) were 8.4 for overall mortality (95\% confidence interval: 4.0-15.9) and 317.9 for deaths due to suicide (95\% confidence interval: 125.2-668.3). These results are in agreement with previous studies, and show that in Brazil non-affective functional psychoses are life-threatening illnesses, which need adequate care, particularly when patients go back to live in the community after hospital discharge.
\end{abstract}

Schizophrenia, mortality. Suicide, statistics.

\section{Resumo}

Estudos sobre mortalidade na esquizofrenia e outras psicoses não afetivas em diversos países industrializados têm consistentemente encontrado índices maiores que aqueles observados na população geral. A principal causa dessa maior mortalidade é o suicídio, ocorrendo em média 20 vezes mais freqüentemente do que na população geral. Esse tópico adquire relevância para a saúde pública no Brasil, em função do aumento previsto no número de casos de psicoses no País devido à mudança de estrutura etária da população, e da política de saúde mental atual, que tem desestimulado a internação psiquiátrica, priorizando o

\footnotetext{
* Part of the Thesis "The outcome of schizophrenia and related psychoses after hospitalization: a 2-year prospective study in São Paulo, Brazil", approved for a PhD degree by the University of London, 1995. Funded by the "Conselho Nacional de Desenvolvimento Científico e Tecnológico/ CNPq" Brasília-Brazil(Process n. 203023-90.0), through Dr. P.R. Menezes scholarship, and "Fundação de Amparo à Pesquisa do Estado de São Paulo" (Process n. 93/0384-8 MEDICINE).

Correspondence to: Paulo R. Menezes - Departamento de Medicina Preventiva da Faculdade de Medicina da Universidade de São Paulo. Av. Dr. Arnaldo, 455 - 01246-903 São Paulo, SP - Brasil. Fax: (011)280.7891 E-mail: pmenezes @ usp.br

The publication of this article was sponsored by FAPESP (Process 95/2290-6).

Received in 1.12.1995. Approved in 29.2.1996.
} 
tratamento das psicoses na comunidade. Para investigar essa questão, realizou-se estudo prospectivo no município de São Paulo, SP (Brasil). A amostra consistiu de 120 internações consecutivas em uma região delimitada daquele município, na faixa etária de 18 a 44 anos, com diagnóstico clínico de psicose funcional não afetiva. A amostra foi seguida por 2 anos a partir da internação psiquiátrica. Ao término desse período, foi possível estabelecer a evolução de 116 pacientes (96.7\%). Sete pacientes faleceram (6\% dos 116 que completaram o estudo), sendo que 5 (4.3\%) cometeram suicídio. Quatro dos casos de suicídio ocorreram durante os primeiros 12 meses após a alta hospitalar. As Razões de Mortalidade padronizadas para idade e sexo (relativos às taxas de mortalidade para a população de São Paulo) foram 8.4 para mortalidade geral (intervalo de confiança de 95\%: 4.0-15.9) e 317.9 para mortes por suicídio (intervalo de confiança de 95\%: 125.2-668.3). Os resultados do presente estudo indicam que as psicoses funcionais não afetivas estão associadas a uma esperança de vida menor que a observada na população geral. Vários países vêm priorizando, já por muitos anos, a atenção psiquiátrica na comunidade. Tanto pacientes e familiares preferem essa alternativa de tratamento ao antigo modelo hospitalocêntrico. No entanto, é necessário que os programas de saúde mental no Brasil forneçam cuidados de saúde adequados aos pacientes que sofrem desses transtornos, particularmente no período que se segue à alta hospitalar, a fim de que se evite ao máximo uma evolução tão desfavorável para os pacientes e seus familiares.

Esquizofrenia, mortalidade. Suicídio, estatística.

\section{INTRODUCTION}

Mortality is an important outcome in schizophrenia and other non-affective functional psychoses, and this has been fully recognized in developed countries. Using a record-linkage strategy, some investigators have been able to follow-up large cohorts of patients for long periods of time and compare mortality rates among such patients with the rates for the corresponding general populations. On average, results have shown that the overall mortality rate among patients with schizophrenia and related psychoses is twice as high as the rate for the general population, and that mortality due to suicide is 20 times higher ${ }^{4,13,14}$. Goldacre et al. ${ }^{9}$ (1993) studied suicide after discharge from psychiatric inpatient care in the UK, and found that for schizophrenic patients the SMR for the first 28 days after discharge was 46 for men and 92 for women, and after that period the risk was lower, with SMR's of 30 for both sexes. In the past these high rates were attributed to the poor living conditions found in the asylums, and now they seem to be associated with the process of transferring care to the community, where many patients lack adequate social support, such as housing, income and health care, and are more exposed to substance abuse ${ }^{17}$. Findings from less developed countries are not so consistent, with some investigators reporting increased mortality rates compared to those of the general population ${ }^{7}$, and others reporting lower rates compared to those observed in developed countries ${ }^{10,20}$. According to Tsuang and Simpson ${ }^{19}$ (1985), research on mortality in psychiatric disorders is important because it can help to identify high risk groups, to monitor changes in patterns of treatment and care over time, to plan intervention strategies to prevent premature deaths and in the assessment of their efficacy.

In Brazil, based on projections for population ageing, it is estimated that from 1985 to the year 2000 there will be an increase of 600,000 cases of schizophrenia, which would represent a $50 \%$ growth in the total number of cases, totalling 1.8 million cases ${ }^{11}$. Schizophrenia accounts for one third of all psychiatric admissions ${ }^{18}$, and consumes around $3 \%$ of all resources spent on hospitalization by the Brazilian National Health Service ${ }^{2}$. However, epidemiological data about the occurrence, characteristics and outcome of schizophrenia in Brazil are scarce. A community-based survey on the prevalence of psychiatric morbidity in Brazil, which was carried out in three urban centres, S. Paulo, Porto Alegre and Brasilia, yielded global prevalence rates for psychoses, as defined by the DSM-III, ranging from $0.2 \%$ to $2.0 \%$ according to the centre concerned ${ }^{1}$. Menezes and $\operatorname{Mann}^{12}$ (1993) found that over 80\% of patients with schizophrenia admitted to psychiatric hospitals in S. Paulo presented with at least some degree of impair- 
ment in social functioning in the month prior to psychiatric admission, of whom $50 \%$ had poor or very poor social functioning, and that $30 \%$ had no source of income, having to rely entirely on relatives or friends for subsistence.

In the 1980's, the mental health policy in Brazil shifted from hospital-based to community-based care. As a consequence, there was a significant decrease in the number of psychiatric beds available ${ }^{2}$. The main responsibility and burden of caring for these patients has been shifting from the asylums to their relatives, and it is likely that this process of transferring care to the community will lead to many patients lacking adequate social support and being exposed to substance abuse, as has been observed in other countries where this process took place many years ago.

Recent changes in the Brazilian public health system, which integrated the services provided by the different levels of administration, led to regional delivery of care to a larger proportion of the population, and created more favourable conditions for the execution of epidemiological investigations on mental health problems ${ }^{16}$. The city of S. Paulo being the largest urban centre in Brazil, with a population of nearly 10 million inhabitants, and its main economic and industrial centre, was one of the pilot areas in this process, and it seemed to be the appropriate setting in wich to carry out a study on mortality in schizophrenia and related psychoses in this country.

\section{METHOD}

The study was carried out in a defined catchment area of the city of S. Paulo, identified as the 'Sistema Descentralizado e Unificado de Saúde - Região 6' (SUDS-R6). The population of the study catchment area in 1991 was nearly 1 million inhabitants. The catchment area had 32 primary care units, of which about one third had at least one mental health worker, two psychiatric outpatient clinics, one emergency unit with a 24-hour psychiatric service, a 20-bed psychiatric ward in a general hospital, and four psychiatric hospitals with about 1500 beds altogether. All psychiatric admissions were centrally recorded at a psychiatric register on a daily basis. The psychiatric register gives priority to individuals living in the study area, where there is no shortage of psychiatric beds.

The study had a prospective design, with a follow-up period of two years from inclusion, and used standardized instruments for the assessment of psychopathological (Present State Examination - 9th version) ${ }^{22}$ and social adjustment levels (Disability Assessment Schedule) ${ }^{24}$ at inclusion. The sample consisted of consecutive admissions aged 18 to 44 years old, to psychiatric hospitals, with an admission diagnosis of either schizophrenia, paranoid psychosis or other functional psychoses, recorded according to the 9th version of the International Classification of Diseases-ICD-9 ${ }^{23}$ (codes 295, 297 or 298, respectively). Subjects with a history of alcohol or drug dependence were excluded. The method of inclusion of subjects and characteristics of the sample investigated has been described in detail elsewhere ${ }^{12}$. Follow-up information was obtained through contacts with patients' informants, carried out at least once during the follow-up period.

\section{Analysis}

Data handling for the index and follow-up phases was done using a computer program for epidemiological studies, the Epi Info version $6^{6}$. To examine whether mortality in the study sample was higher than the rates for the general population, Standardized Mortality Ratios (SMR's) were estimated using age- and sex-specific rates for the population of the city of S. Paulo in the year 1991. Significance tests for SMR's were based on the exact $p$-value in the Poisson distribution table for the probability of getting the observed number of events given the expected number ${ }^{5}$, and a $p$-value equal or lower than 0.05 was considered statistically significant. Ninety-five per cent confidence intervals for the SMR's were calculated under the same assumption of a Poisson distribution, using a table for confidence intervals ${ }^{8}$.

\section{RESULTS}

One hundred and twenty-four subjects were included in the study, in the period between June and September 1991. Follow-up assessments were carried out from May to September 1993. Four subjects $(3.3 \%)$ could not be traced. Another 6 were traced but could not be interviewed because they were living in other regions of the country (sometimes as far as 2,000 miles from S. Paulo), but they were reported to be alive by their contacts in S. Paulo. Seven patients had died by the time of follow-up. The mean length of follow-up for the remaining 107 subjects was 102.4 weeks (s.d.=3.2), ranging from 97 to 113 weeks. Four subjects were excluded from the study after being assessed at 2-year follow-up, because when their notes were re-checked no history or symptom suggestive of schizophrenia or related psychoses either before inclusion to the study or during the 2-year follow-up was discovered. Two had a clear clinical picture of bipolar disorder without psychotic symptoms, and the other 2 of depressive disorder without psychotic symptoms.

Of the 7 subjects who died during the follow-up period $(6 \%$ of the cohort of 116 , which included the 103 subjects re-assessed at 2-year follow-up and the 6 subjects traced and not re-assessed but known to be alive), 5 (4.3\%) were suicides and $2(1.7 \%)$ died 
from medical conditions (Table 1). For the whole cohort, the SMR for overall mortality was 8.4, meaning that the overall mortality among the cohort was 8 times higher than the rate for the general population (Table 2). The SMR for men was 4.5 , and that for women was 25.5. The probabilities that the SMR's for overall mortality were different from 1 were all statistically significant. For the whole cohort, the SMR for deaths due to suicide was 318 , and again women had a higher relative mortality rate than men, with SMR's of 1107 and 154, respectively. The prob- abilities that the SMR's for suicide were different from 1 were all statistically significant. No clinical characteristics differentiated those who commited suicide from those who did not, except for the presence of depressive symptoms at the time of index admission. Four of the five patients who commited suicide presented with at least one depressive symptom at index assessment, whereas the prevalence of depressive symptoms in the whole cohort was $38.8 \%$. This difference did not reach statistical significance, however (Fisher exact test, 2-tailed, $\mathrm{p}=0.07$ ).

Table 1 - Characteristics of the subjects who died during the follow-up period and causes of death.

\begin{tabular}{lcccll}
\hline Sex & Age & $\begin{array}{c}\text { Number of previous } \\
\text { admissions }\end{array}$ & $\begin{array}{c}\text { Length of } \\
\text { illness } \\
\text { (years) }\end{array}$ & $\begin{array}{c}\text { Depressive } \\
\text { symptoms }\end{array}$ & Cause of death \\
\hline Male & 22 & 0 & 1 & yes & suicide (hanging, while in hospital) \\
Male & 29 & +10 & 9 & no & suicide (jumped from height) \\
Female & 40 & +10 & 12 & yes & suicide (jumped in front of a lorry) \\
Female & 30 & 0 & 2 & yes & suicide (relatives did not reveal method) \\
Female & 36 & 3 & 11 & yes & suicide (burning) \\
Male & 34 & +10 & 12 & yes & stomach haemorrhage \\
Female & 44 & 4 & 12 & yes & sudden death (unknown cause) \\
\hline
\end{tabular}

Table 2 - Observed and expected number of deaths, and Standardized Mortality Ratios (SMR) for overall deaths and suicide in a cohort of patients with non-affective functional psychoses followed up for 2 years $(n=116)$.

\begin{tabular}{|c|c|c|c|c|c|}
\hline & \multicolumn{2}{|c|}{ Deaths } & \multirow[t]{2}{*}{ SMR } & \multirow[t]{2}{*}{ 95\%C.I. } & \multirow[t]{2}{*}{$\mathrm{p}$} \\
\hline & Observed & Expected & & & \\
\hline Overall & 7 & 0.83 & 8.4 & $4.0-15.9$ & $<0.001$ \\
\hline Men & 3 & 0.67 & 4.5 & $1.2-11.5$ & 0.03 \\
\hline Women & 4 & 0.16 & 25.5 & 8.7-58.5 & $<0.001$ \\
\hline Suicide & 5 & 0.016 & 317.9 & $125.2-668.3$ & $<0.001$ \\
\hline Men & 2 & 0.013 & 153.6 & 27.3-483.6 & $<0.005$ \\
\hline Women & 3 & 0.003 & 1107.0 & $301.8-2861.2$ & $<0.001$ \\
\hline
\end{tabular}

SMR - Standardized Mortality Ratios

\section{DISCUSSION}

To our knowledge, this is the first study to investigate mortality among individuals with schizophrenia and related psychoses in a catchment area-based sample in Brazil. Mortality in the study sample was 8 times higher than what would have been expected according to population rates for the city of S. Paulo, and was mainly due to an excess of deaths by suicide. These findings will be discussed in terms of methodological considerations, consistency with the literature and implications for service planning and future research.

\section{Methodological Considerations}

The strategy used in the present study was an intensive follow-up of a small sample for a fixed short period of time, the high follow-up rate being one of the strengths of this approach. Hence, information was unavailable for only a few probands $(3.3 \%$ of the subjects could not be traced), and was obtained directly from subjects' informants, who in most situations gave a detailed picture of the circumstances of death. The main disadvantage was the small size of the sample, which limited the possibility of examining risk factors which might be associated with overall mortality, and particularly with suicide. Nevertheless, this was the only available alternative for such a study in Brazil, since there are no psychiatric registers which would allow a linkage-type study of a large sample of patients.

It was not possible, for a number of reasons, to obtain death certificates for all the deceased subjects; therefore, in the present study, cause of death was 
obtained from informants, whereas the rates for mortality due to suicide in the general population came from figures based on death certificates. There is evidence that suicide is under-reported as the main cause of death in many countries, with an 'open' verdict given in cases where there is not absolute certainty about the intentional behind the cause of death ${ }^{15}$. Therefore, both the population rates for deaths due to suicide and the rates for suicide among schizophrenic patients might be officially underestimated in such countries. That might be the case in Brazil as well, and the SMR's found in the present study may be an overestimation of the true rate. However, even if this is the case, the SMR's for deaths due to suicide are extremely high, and should not be disregarded.

The sample of the present study is not representative of all patients with non-affective functional psychoses that are admitted to psychiatric hospitals in S. Paulo. The limit in the age range excluded older patients from the study, and they have a lower risk of suicide, according to the literature ${ }^{4,13}$. On the other hand, patients with alcohol or drug dependence were also excluded, and they may have higher risks for overall mortality and suicide.

\section{Mortality among Individuals with Schizophrenia and related Psychoses}

The SMR for overall mortality was 8.4 , with a $95 \%$ confidence interval ranging from 4 to 16 , indicating that patients with schizophrenia experience much higher mortality rates than the general population, when taking into account age and sex-specific rates. Women had an SMR 5 times higher than men. This was so because in the general population mortality rates for women are much lower than those for men, whereas the number of deaths in the cohort were 4 and 3, respectively. The increased mortality was mainly due to suicides ( 5 of the 7 deaths observed during the follow-up period), which were over 300 times higher than the rate for the general population, being 150 times higher for men and 1100 times higher for women. Several studies have shown that patients with schizophrenia have higher mortality rates than the general population, overall mortality being on average twice as high, and deaths due to suicide being on average 20 times higher ${ }^{4,13,14}$. The SMR estimate for deaths due to suicide in the present study was much higher than those described in the literature. Confidence intervals were wide, but even the lower values were far above 20. One of the possible explanations has already been discussed, that is, an overestimation of the SMR's due to different methods for ascertainment of cause of death for the sample and for the general population. Another possibility is the fact that suicide rates in the general population in S. Paulo are lower than those observed in those countries where such a study has been carried out, and therefore the SMR for S. Paulo could be higher, even if the rate of suicide among schizophrenic patients is comparable to the rates from these countries. Nevertheless, this study has produced evidence to show that the mortality rate among schizophrenic patients in S. Paulo is high, and suicide is the main cause. It is notable that all suicides occurred during the first year of follow-up, one of them during the index admission. Black et $\mathrm{al}^{4}$. (1985) also found increased mortality risk during the first 2 years after hospital discharge. Although it was not possible in the present study to obtain information on the exact time after hospital discharge at which these suicides occurred, these findings agree with those of Goldacre et $\mathrm{al}^{9}$. (1993), who found that the highest period of risk for suicide after hospital discharge was the period immediately after it, and that the suicide risk decreasing and stabilized with time.

\section{Implications of the Present Findings}

The Brazilian Ministry of Health has made a clear option in favour of a policy of community-based care for the mentally ill, and deinstitutionalization of chronic psychiatric patients ${ }^{2}$. All patients included in the present study were living in the community before their index admission, and most of them were not chronic long-stay patients. The majority of them went back to live in the community after a median of four months, confirming this trend towards reducing the use of inpatient care and giving priority to community-based aftercare. Experience from other countries has shown that community-based care, as opposed by hospital-based care, is the option prefered by both patients and relatives ${ }^{3}$, and its implementation in Brazil has rendered some successful examples. Nevertheless, it is necessary to be aware that increased mortality, particularly due to suicide, is an important unfavourable outcome, and must be tackled by all possible means. Although some risk factors for suicide have been identified, the identification of those individuals who actually commit suicide prior to the fatal event is very difficult ${ }^{21}$. Mental health professionals should be aware that the period following discharge is the most critical in terms of risk of suicide, and adequate provision of aftercare might be the best measure to adopt in the attempt to 
reduce such a risk. Similar studies should be carried out in other urban centres and in rural areas, to discover whether there are regional variations in mortality rates among those suffering from non-affective psychoses, and if this is the case, what would be

\section{REFERENCES}

1. ALMEIDA $F^{\circ}$, N. et al. Estudo multicêntrico de morbidade psiquiátrica em áreas urbanas brasileiras (Brasília, São Paulo, Porto Alegre). Rev. ABP-APAL, 14:93-104, 1992.

2. ALVES, D.S.N. et al. Elementos para uma análise da assistência em saúde mental no Brasil. J Bras. Psiquiatr. 41:423-6, 1992.

3. ANDERSON, J. et al. The TAPS Project. 13: clinical and social outcomes of long-stay psychiatric patients after one year in the community. Br. J. Psychiatry,162 (Suppl. 19):45-56, 1993.

4. BLACK, D.W. et al. Excess mortality among psychiatric patients: the Iowa Record-Linkage Study. JAMA, 253:58-61, 1985.

5. BRESLOW, N.E. \& DAY, N.E. Statistical methods in cancer research; vol. 2. The design and analysis of cohort studies. Lyon, IARC, 1987.

6. DEAN, A.G., et al. Epi Info, version 6: a word processing, database, and statistics program for epidemiology on microcomputers. Atlanta, Centers for Disease Control and Prevention, 1994

7. DUBE, K.C. et al. Long term course and outcome of the Agra cases in the international Pilot Study of Schizophrenia. Acta Psychiatr. Scand., 70:170-9, 1984.

8. GARDNER, M.J. \& ALTMAN, D.G. Statistics with confidence. London, British Medical Journal, 1989.

9. GOLDACRE, M.J. et al. Suicide after discharge from psychiatric inpatient care. Lancet, 342:283-6, 1993.

10. LEON, C.A. Clinical course and outcome of schizophrenia in Cali, Colombia: a 10-year follow-up study. J Nerv. Ment. Dis., 177:593-606, 1989.

11. LEVAV, I. et al. Salud mental para todos en America Latina y el Caribe: bases epidemiologicas para la accion. Bol. Oficina Sanit. Panam., 107:196-219, 1989.

12. MENEZES, P.R. \& MANN, A.H. The social adjustment of patients with schizophrenia: implications to the mental health policy in Brazil. Rev. Saúde Pública, 27:340-9, 1993. the possible reasons for such a variation might be The development of information systems would allow the monitoring of mortality rates over time, and this might bring important insights into the effectiveness of the mental health care system.
13. MORTENSEN, P.B. \& JUEL, K. Mortality and causes of death in first admitted schizophrenic patients. $B r . J$. Psychiatry, 163:183-9, 1993

14. NEWMAN, S.C. \& BLAND, R.C. Mortality in a cohort of patients with schizophrenia: a record linkage study. Can. $J$. Psychiatry, 36:239-45, 1991

15. SAINSBURY, P. The epidemiology of suicide. In: Roy, A Suicide. Baltimore, Williams and Wilkins, 1986. p. 17-40.

16. SANTANA, V.S. et al. Revisão dos estudos epidemiológicos em saúde mental no Brasil. $1^{\text {a }}$ parte. J. Bras. Psiquiatria, 37:227-31, 1988

17. SIMPSON, J.C. Mortality studies in schizophrenia. In: Tsuang, M.T. \& Simpson, J.C. Handbook of schizophrenia; vol. 3 - Nosology, epidemiology and genetics. Amsterdam, Elsevier Science Publishers, 1988. v. 3 p. 245-73

18. SOUZA, C.M. Epidemiologia em medicina clínica. Educ. Med. Salud, 17:83-7, 1983.

19. TSUANG, M.T. \& SIMPSON, J.C. Mortality studies in Psychiatry. Arch. Gen. Psychiatry, 42:98-103, 1985.

20. VERGHESE, A. et al. Factors associated with the course and outcome of schizophrenia in India: results of a two-year multicentre follow-up study. Br. J. Psychiatry, 154:499-503, 1989.

21. WILKINSON, G. Can suicide be prevented? Better treatment of mental illness is more appropriate aim. $B M J$, 309:860-1, 1994.

22. WING, J.K. et al. Measurement and classification of psychiatric symptoms: an instruction manual for the PSE and Catego Program. London, Cambridge University Press, 1974.

23. WORLD HEALTH ORGANIZATION. International classification of diseases: 9th version. Geneva, 1975.

24. WORLD HEALTH ORGANIZATION. Psychiatric disability assessment schedule. Geneva, 1988. (WHO/DAS). 